\title{
Analysis of Technical Efficiency and Its Determinants among Small Scale Rice Farmers in Patigi Local Government Area of Kwara State, Nigeria
}

\author{
Y. U. Oladimeji and Z. Abdulsalam, \\ Department of Agricultural Economics and Rural Sociology, Ahmadu Bello University, P.M.B. 1044, Zaria, \\ Kaduna State, Nigeria
}

\begin{abstract}
The study examined technical efficiency and its determinants among small scale rice farmers in Patigi Local Government Areas of Kwara State. A systematic random sampling technique was used to select one hundred and twenty rice farmers for the study. Primary data were obtained with the aid of well structured questionnaire and interview schedule. Descriptive statistics and stochastic production frontier model were employed in the analysis of the data. $60 \%$ of the rice farmers had one form of education or the other while the age of rice farmers ranges from between 18 to 67 years with mean age of 38 years. The result of technical efficiency shows that the mean was approximately 0.65. The minimum technical efficiency was 0.10 while the maximum was 0.93. The determinants of technical efficiency in the study area were household size, farming experience, level of education, labour, farm size and non farm income in paddy rice production. It was recommended that the government at all levels should provide labour saving technology, social services and support and ensure farmers are educated to ensure proper understanding of indices of technical efficiency with attendance boost in rice yield.
\end{abstract}

Keywords: Technical efficiency, Determinant, Rice, Patigi, Kwara State

\section{Introduction}

Rice is a staple food for about 2.6 billion people in the world. It is the leading Cereal crop of south and east Asia, which are thickly populated regions of the world and the global output shows that the Asian continent account for about 92 percent, while American and Caribbean account for 5 percent and 3 percent for Africa (Oyewole et al., 2010). It is also the most important staple food for large part of the world human population. It is the second highest worldwide production after maize (FAOSTAT, 2006). Since a large portion of maize crops are grown for the purpose other than human consumption; rice is the most important grain with regard to human nutrition and calorie intake (Usman, 2011). Rice provides more than one fifth of the calorie consumed worldwide by human species, though relatively lower in protein compare to other cereals, it contains a better balance of amino acids (Oyewole et al., 2010).

Nigeria is the leading consumer and largest producers of rice in Africa and simultaneously one of the largest rice importers in the world. As well as an important food security crop, it is an essential cash crop for it is mainly small-scale producers who commonly sell 80 per cent of total production and consume only 20 per cent. Rice generates more income for Nigerian farmers than any other cash crop in the country. In 2008, Nigeria produced approximately 2 million metric tonnes of milled rice and imported roughly 3 million metric tonnes, including the estimated 800,000 metric tonnes that is suspected to enter the country illegally on an annual basis (NBS, 2013)

Although, rice has been cultivated in Nigeria for more than one hundred years, its production and consumption did not gain much recognition until the early 1970's when the supply of tradition food commodities such as yam, maize, sorghum and the millet suffered considerable short fall because of the civil war July 1967 to January 1970 (Usman, 2010). Therefore, over the past several decades rice has established itself as a preferred staple food in Nigeria. Once reserve for ceremonial occasions, rice has grown in importance as a component of Nigerian diets. An average Nigerian consumes about $24.8 \mathrm{~kg}$ of rice per year, representing 9 percent of the total calories intake (FAO, 2001). In addition due to its increasing constitution of per capita caloric consumption of Nigerians, the demand for rice has been increasing at a much faster rate than domestics production and more than many other Africa countries since Mid 1970 (FAO, 2001).

The Nigerian rice sub-sector witnessed a remarkable increase in output of 2.5 million metric tonnes in 1990 to about 4.2 million metric tonnes in 2008. This increase in output of rice over the years was as a result of increase in hectare cultivated. However, there has been falling yield of kg per hectare of rice from $2,069.54 \mathrm{~kg} / \mathrm{ha}$ in 1990 to $1,754.47 \mathrm{~kg} / \mathrm{ha}$ in 2008 which led to supply deficit situation in the country (FAO, 2010). The demand for rice in Nigeria as at 2007 was estimated and put at 13.5million tons against the current production level of 3.2 million tonnes (CBN, 2007), thus creating a gap of about 10.3 million tonnes. However, Nigeria is one of 
the most resources endowed nation to produce enough rice not only for domestic consumption but also for export. It has a land area of 98.3 million hectares of which 79 million hectares is arable. In addition the population is about 160 million and between $60-70 \%$ of the population is involved in agriculture (Akinwumi et al., 2011; FAO, 2013). Despite this, the land area put to arable crop cultivation is about 2.2 million hectares, dominated by small holder farmers with 0.5 to 2 hectares per farmer, using manual labour for virtually all operations (Oyewole et al., 2010).

The inability of Nigeria rice Sub-sector to meet the domestic needs could be attributed to low production, inefficiency in the use of resources, disincentives from macro-economic environment and production in the hand of small scale farmers who use traditional technology (Federal Ministry of Agriculture, 1995).It become imperative to assess factors underlying inefficiency in the use of resources that will enhance small scale farmers to be technically efficient and for designing policies to meet the needs and well being of farmers. The study was therefore conducted to examine the socio economic characteristics of small holder rice farmers, specifically estimate the technical efficiency and identify the determinant of technical efficiency among small holder rice farmers.

\section{Materials and Methods}

The study was conducted in Patigi Local Government Area of Kwara State, Nigeria. The state is located between latitudes $7^{\circ} 45^{\prime} \mathrm{N}$ and $9^{\circ} 30^{\prime} \mathrm{N}$ and longitude $2^{0} 30^{\prime} \mathrm{E}$ and $6^{0} 25^{\prime} \mathrm{E}$ and a total land area of $3,682,500$ hectares and 247,975 farm families with majority living in rural areas. The state has a population of about 2,365,353 people in 2006 according to the National Population Census (NPC, 2006). This is projected in 2012 to be 2,857,420, representing 3.2\% annual growth rate in population and an average density of eighty eight persons per square kilometre (NPC, 2006; KWADP 2011). It is bounded in the North by Niger State, to the South by Oyo, Osun and Ekiti states, to the East by Kogi state and to the west by Benin Republic. It comprises of 16 Administrative Local Government Areas, divided into four agricultural zones by the Kwara State Agricultural Development Project (KWADP) in consonance with ecological characteristics, cultural practices and project administrative. The zones are: zone A; Baruten and Kaima LGAs; Zone B; Edu and Patigi LGAs; Zone C; Asa, Ilorin East, Ilorin South, Ilorin West and Moro LGAs and Zone D; Ekiti, Ifelodun, Irepodun, Offa, Oyun, Isin and Oke Ero LGAs. The climate of the study area is derived savannah with two main distinct seasons: the wet and dry season. The annual rainfall ranges from $800 \mathrm{~mm}$ to $1500 \mathrm{~mm}$ per annum. The vegetation in the state consists largely of with a great expanse of arable land and rich fertile soil with crops like rice, maize, yam, sweet potatoes, cassava and vegetable grown. The state has high potential for livestock rearing especially goats, pigs, sheep and poultry. Kwara State is essentially agrarian with about 80 percent of the population living in the rural areas and more that 90 percent of the rural population engages in farming (KWADP, 2008).

Primary data were used for this study. Farm level survey provided the basic cross-sectional data from 120 rice farming households in the study area. Data were collected from rice farmers with the aid of structured questionnaire and interview schedule. These include farm size, labour, quantity of fertilizer and chemical used as well as their socio economic characteristics

A systematic random sampling technique was used to select the representative rice farming households that were used for this study. The first stage was random selection of 6 villages out of the list of rice farming villages/settlements in the Patigi Local Government. The second stage sampling was the random selection of 20 rice farming households per settlement to make a total of 120 rice farming household for this study.

\section{Technical Efficiency Analysis}

The cobb Douglas functional form of the stochastic production frontier was employed to estimate the technical efficiency of rice farmers in the study area. The stochastic production frontier model has the advantage of allowing simultaneous estimation of individual technical efficiency of the farmers as well as its determinant of technical efficiency (Battese and Coelli, 1977). It is specified as

Ln $Y_{1}=\beta_{0}+\beta_{1} X_{1}+\beta_{2} X_{2}+\beta_{3} X_{3}+\beta_{4} X_{4}+\beta_{5} X_{5}+\beta_{6} X_{6}+V_{1}+V_{2} \ldots \ldots \ldots \ldots \ldots$ (1)

Where:

$\mathrm{Ln}=$ The natural logarithm

$\mathrm{Y}_{1}=$ Output in kilogramme $(\mathrm{kg})$

$\mathrm{X}_{1}=$ Farm Size (hectares)

$\mathrm{X}_{2}=$ Seed in kilogramme $(\mathrm{kg})$

$\mathrm{X}_{3}=$ Fertilizer in litres $(\mathrm{L})$

$\mathrm{X}_{4}=$ Herbicides in litres $(\mathrm{L})$

$\mathrm{X}_{5}=$ Labour (Labour-hour)

$\mathrm{X}_{6}=$ Extension contact (no. of visits) 
$\mathrm{V}_{1}=$ Error term not under the control of farmers

$\mathrm{V}_{2}=$ Error term under the control of farmers technical inefficiency

$\beta_{0}=$ Intercept

$\beta_{1}-\beta_{6}=$ Parameters to be estimated

The determinant of technical efficiency was modeled in terms of factors that are assumed to affect the efficiency of production of farmers, most importantly socio economic variables of the farmers.

The determinants of the technical inefficiency $\left(\mathrm{U}_{\mathrm{i}}\right)$ was modeled and defined by:

$\mathrm{U}_{\mathrm{i}}=\mathrm{B}_{0}+\mathrm{B}_{1} \mathrm{Z}_{1}+\mathrm{B}_{2} \mathrm{Z}_{2}+\mathrm{B}_{3} \mathrm{Z}_{3}+\mathrm{B}_{4} \mathrm{Z}_{4}+\mathrm{B}_{5} \mathrm{Z}_{5}+\mathrm{B}_{6} \mathrm{Z}_{6}+\mathrm{B}_{7} \mathrm{Z}_{7}+\mathrm{B}_{8} \mathrm{Z}_{8}+\mathrm{B}_{9} \mathrm{Z}_{9}+\mathrm{e}$

Where

$\mathrm{X}_{1}=$ Age (years)

$X_{2}=$ Number of Household size

$\mathrm{X}_{3}=$ Farming experience (years)

$\mathrm{X}_{4}=$ Level of Education (years)

$\mathrm{X}_{5}=$ Access to fertilizer

$\mathrm{X}_{6}=$ Labour (Labour hour)

$\mathrm{X}_{7}=$ Extension contact (No. of visits)

$\mathrm{X}_{8}=$ Farm size

$\mathrm{X}_{9}=$ non farm income

$\mathrm{e}=$ Error term

\section{Results And Discussion}

\section{Socio-economic characteristic of Rice farmers in the study area}

Table 1 show that the age of the rice farmers ranges between 18 to 67years and mean age of 42 years. This implies that majority of farmers were middle age and there is likelihood of increase productivity in rice production. The finding agreed with Idiong et al., (2007). All things being equal, labour productivity is a function of age because it is believed that old people tends to adhere strictly to traditional methods of production while young people tends to be more willing to adopt new production methods in order to increase their output. Age is also importance in farming because it determines the agility and physical strength of the farmers. The marital status shows that majority of the 80 respondents (66.6\%) of the farmers are married. Marrying more than one wife is common in rural settings mostly to ensure supply of additional family labour or to raise the status of the farmer in an illiterate setting. However, Ogundele and Okoruwa (2006) reported that higher family size does not necessarily translate to higher use of family labour because some of these young able men prefer other job than farming. $60 \%$ of the farmers had one form of education or the other while $40 \%$ of the respondents had no education. Education could affect their chances of using improved and sophisticated inputs which can boost rice output. Most modern implement requires skilled training and reading manuals for proper understanding of their operations (finding synonymous with Mohammed-Lawal et al., 2009). However, more than 78 respondents $(65 \%)$ have farm size greater than 1.5 ha. This was attributed partly to supply of adequate inputs in form of tractors and fertilizer to the farmers in the study area by different government agents and to higher level of education of the majority of the respondents. The analysis of years of experience shows that there were more new entrants into the farming activities is the study area. More than half of the respondents (66 or 55\%) had less than 12 years of entrants into the rice farming. This was attributed to drift of youth to farming as a result of lack of white collar job after finishing schools. However, years of farming experience as observed by Ajani, (2000) as a factor that enhances agricultural productivity among farming households in Nigeria.

Table 1: Socio Economic characteristics of small scale rice farmers in Patigi Local Government Area, Kwara State

\begin{tabular}{|c|c|c|}
\hline VARIABLE AGE & FREQUENCY & PERCENTAGE \\
\hline $18-27$ & 39 & 32.5 \\
\hline $28-37$ & 28 & 23.3 \\
\hline $38-47$ & 14 & 11.7 \\
\hline $48-57$ & 26 & 21.7 \\
\hline $58-$ Above & 13 & 10.8 \\
\hline Total & $\mathbf{1 2 0}$ & $\mathbf{1 0 0}$ \\
\hline
\end{tabular}

\begin{tabular}{|c|c|c|}
\hline Education & FREQUENCY & PERCENTAGE \\
\hline No education & 48 & 40.0 \\
\hline Primary Education & 14 & 11.7 \\
\hline Secondary Education & 51 & 42.5 \\
\hline
\end{tabular}




\begin{tabular}{|c|c|c|}
\hline Tertiary Education & 04 & 3.3 \\
\hline Adult Education & 03 & 2.5 \\
\hline Total & $\mathbf{1 2 0}$ & $\mathbf{1 0 0}$ \\
\hline \multicolumn{2}{|c|}{ PERCENTAGE } \\
\hline GENDER & FREQUENCY & 81.7 \\
\hline Male & 98 & 18.3 \\
\hline Female & 22 & $\mathbf{1 0 0}$ \\
\hline Total & $\mathbf{1 2 0}$ & \\
\hline
\end{tabular}

\begin{tabular}{|c|c|c|}
\hline MARITAL STATUS & FREQUENCY & PERCENTAGE \\
\hline Married & 80 & 66.6 \\
\hline Single & 20 & 16.7 \\
\hline Divorced & 11 & 9.2 \\
\hline Widowed & 9 & 7.5 \\
\hline Total & $\mathbf{1 2 0}$ & $\mathbf{1 0 0}$ \\
\hline
\end{tabular}

\begin{tabular}{|c|c|c|}
\hline YEAR OF EXPERIENCE & FREQUENCY & PERCENTAGE \\
\hline $1-6$ & 30 & 25.0 \\
\hline $7-12$ & 36 & 30.0 \\
\hline $13-18$ & 14 & 11.7 \\
\hline $19-24$ & 21 & 17.5 \\
\hline $25-30$ & 09 & 7.5 \\
\hline $31-36$ & 10 & 8.3 \\
\hline Total & $\mathbf{1 2 0}$ & $\mathbf{1 0 0}$ \\
\hline
\end{tabular}

\begin{tabular}{|c|c|c|}
\hline FARM SIZE (HA) & FREQUENCY & PERCENTAGE \\
\hline $01-0.5$ & 10 & 33.3 \\
\hline $0.6-1.0$ & 15 & 12.5 \\
\hline $1.1-1.5$ & 17 & 14.2 \\
\hline $1.6-2.0$ & 28 & 23.3 \\
\hline $2.1-2.5$ & 50 & 41.7 \\
\hline Total & $\mathbf{1 2 0}$ & $\mathbf{1 0 0}$ \\
\hline
\end{tabular}

\section{Source field survey, 2012}

\section{Technical efficiency of small scale rice farmers in the study area}

Table 2 shows the frequency distribution of the production frontier model. The technical efficiency of rice farmers was estimated using cobb-Douglas functional form of stochastic production frontier. The model allows for technical inefficiency and that random shock outside the control of the farmer can affect output.

From the table 2, the result revealed that about $43 \%$ of the farmers operated below the efficiency level of $46 \%$ while about $28 \%$ of the farmers attained efficiency greater that $58 \%$. In addition more than half $(52.5 \%)$ of the rice farmers attained a ranged efficiency of between $34-57 \%$. The mean technical efficiency for the 120 sample is about $65 \%$ with a minimum technical efficiency of about $10 \%$ and maximum technical efficiency of $0.93(93 \%)$. The mean technical efficiency of approximately 0.648 shows that the farmers are able to obtain about 0.650 unit (or 65\%) of potential outputs from a given one unit mix of production input. Therefore the rice farmers can expand their output further by a relatively high margin of $35 \%$ by adopting a superior improve techniques and technology to attained the technical efficiency of one. The result is synonymous with Oniah et al., (2008); Mohammed-lawal et al., (2009); Oyewole and Ebukiba, (2010) and Usman, (2011).

Table 2: Technical efficiency of small scale farmers in Patigi local government Area, kwara state

\begin{tabular}{|c|c|c|}
\hline EFFICIENCY INDEX & FREQUENCY & PERCENTAGE \\
\hline $0.10-0.21$ & 14 & 11.7 \\
\hline $0.22-0.33$ & 10 & 8.3 \\
\hline $0.34-0.45$ & 27 & 22.5 \\
\hline $0.46-0.57$ & 36 & 30.0 \\
\hline $0.58-0.69$ & 14 & 11.7 \\
\hline $0.70-0.81$ & 08 & 6.7 \\
\hline $0.82-0.93$ & 11 & 9.1 \\
\hline Total & $\mathbf{1 2 0}$ & $\mathbf{1 0 0}$ \\
\hline
\end{tabular}

Mean Technical efficiency $=0.648212$ 
Minimum technical efficiency $=0.10022$

Maximum Technical Efficiency $=0.93$

Source: data Analysis, 2010

\section{Determinants of Technical Efficiency}

Table 3 summarizes the factors that determined the technical efficiency of the rice farmers in Patigi local government area of kwara state. The determinants include household size, farming experience level of education labour, farm size and non-farm income. The result shows the regression co-efficient, standard error and $\mathrm{t}$-value. The $\mathrm{t}$-value indicates how the factors are related with the dependent variable (paddy rice) at $1 \%, 5 \%$ and $10 \%$ significant rates.

The co-efficient of Age, extension contact and access to fertilizer were not significant; findings in contrast with Ajibefun and Abdulkadir, (2004); Ajani, (2000) and Amaza and Maurice, (2005). However, Household size is important in the supply of family labour because increase in household size leads to increase in technical inefficiency as well as output, ceteris paribus, and was significant at 5\%.The result was synonymous with Mohammed-lawal et al., (2009) and Usman, (2011). In the same vein, coefficient of labour was statistically significant at $1 \%$ which shows that increase in the use of labour would increase farm output in the study area; perhaps, most rice farming operations from pre-planting to processing is labour intensive particularly in the study area. This finding is synonymous with Muhammed-lawal et al., (2009); Amaza and Maurce, (2005) and Usman, (2011). Farming experience was also significant at 5\% as a determinant of technical efficiency. The implications are that farmers tend to be more active, acquire more skills and training as they spend more years in production which culminates in increase productivity. The result was in line with Amaza and Maurice, (2005); Idiong et al., (2007) and Oyewole and Ebukiba, (2010); but in contrary to Okoruwa and Ogundele, (2006). Coefficent of education was positive and significant at 5\% which implies that higher level of education increase their chances of using improved and sophisticated technology and techniques which require training and reading manuals and has attendance increase in yield and optimum use of input resources. This finding is synonymous with Muhammed-lawal et al., (2009); Amaza and Maurce, (2005). Farm size was positive and significant at $10 \%$ which implies increase output because as farm size increase, the yield will also increase ceteris paribus. Non-farm income was also significant. The proceed from non farm income can assist the farmers to procure the needed inputs such as fertilizers chemical and hired labour which are timely required in farming activities. The result, however contrast Okoruwa and Ogundele, (2006) and usman, (2011) that nonfarm income had no influence on the technical efficiency of rice farmers in the study area.

Table 3: Determinants of technical efficiency of rice farmers in Patigi local government area of kwara state

\begin{tabular}{|c|c|c|c|}
\hline Variable & $\begin{array}{c}\text { Co-efficient } \\
(\boldsymbol{\beta})\end{array}$ & $\begin{array}{c}\text { Standard error } \\
(\mathbf{S E})\end{array}$ & T-value \\
\hline Constant & 1.10635 & 1.320416 & $0.838^{*}$ \\
\hline Household Size & 432.271 & 289.498 & $1.493^{* *}$ \\
\hline Farming Experience & 59.321 & 28.421 & $2.087^{* *}$ \\
\hline Level Of Education & 298.111 & 173.624 & $1.716^{* *}$ \\
\hline Access to Fertilizer & 0.837 & 2.648 & $0.316^{\text {NS }}$ \\
\hline Age & 26.731 & 40.698 & $0.657^{\text {NS }}$ \\
\hline Labour & 400.638 & 76.431 & $5.242^{* *}$ \\
\hline Extension Contact & 9.621 & 13.890 & $0.692^{\text {NS }}$ \\
\hline Farm Size & 487.318 & 109.621 & $4.445^{*}$ \\
\hline Non-farm Income & 622.3 & 899.311 & $6.920^{*}$ \\
\hline
\end{tabular}

Note

***: Significant at 1\%

**: Significant at 5\%

*: Significant at $\mathbf{1 0 \%}$

Ns: Not significant

\section{Conclusion And Recommendation}

The study shows that the rice farmers were about $65 \%$ technically efficient. The determinants of technical efficiency in the study area include: Household size, farming experience, level of education, labour, farm size and non farm income. However, labour was the most limited resource for rice production in the study area and found to be statistically significant at $1 \%$. It is recommended, therefore that rice farmers in the local government area should be provided with labour saving technology to reduce over dependency on young household members who may need to go to school. Farmers should be educated to ensure proper understanding of indices of technical efficiency so that farmers would improve the uses of available resources to achieve a 
higher technical efficiency. This would also induce the farmers to come closer to technical efficiency of one through adopting of technology capable of increasing not only the profitability of the enterprise but also make efficient use of fishing resource.

\section{References}

[1]. Ajani, O. I. Y., 2000. Resource productivity in food farming in Northern area of Oyo State, Nigeria. Unpublished PhD Thesis, Department of Agricultural Economics, University of Ibadan, Ibadan. Nigeria.

[2]. Ajibefun, I. A. and A. O. Abdulkadir, 2004. Impact of Size Farm Operation on Resource Use Efficency in Small Scale Farming: Evidence from South Western Nigeria. J. of Food, Agric. and Environ. 2(1): 359-364

[3]. Akinwumi, F.O., Akinwumi, I.O. and Ogundahunsi, O.A. 2011. Characterization of Artisan Fishery in the Coastal Area of Ondo State, Nigeria. International Research Journal of Agricultural Science and Soil Science. 1(3): 83-89

[4]. Amaza, P.S. and D. C. Maurice, 2005. Identification of Factors that Influence Technical Efficiency of Rice Based Production System in Nigeria: A Paper presented at workshop on policies and strategies for promoting Rice Production and Food Security in Sub-Sahara Africa, Cotonou, Benin.

[5]. Battese, G.E. and G. S. Coelli, 1977. Estimation of a Production Frontier Model with Application to the Pastoral zone of Eastern Nigeria. Australia J. of Agric. Econs. Vol. 21.

[6]. CBN (Central Bank of Nigeria), 2007. Central Bank of Nigeria. Yearly Report 2007 Edition.

[7]. FAO (Food and Agriculture Organization), 2001. Food and Agricultural Organization Report.

[8]. Food and Agriculture Organization, (2013). FAO Country Programming Framework (CPF) Federal Republic of Nigeria, Fiat Panis, pp $1-41$

[9]. FAOSTAT, 2006. Online Datase. Available at http://faostatfao.org and http://en.wikipedia.org/ wiki/rice Food and Agriculture Organization of United Nations. Rome

[10]. FAO, (Food and Agriculture Organization), 2010. Online Datase, Available at http://faostatfao.org and http://en.wikipedia.org/wiki/rice Food and Agriculture Organization of United Nations. Rome.

[11]. FMA (Federal Ministry of Agriculture), 1995. Planning Research and Statistical Data IITA 1994, IITA Annual Report, Ibadan, Nigeria.

[12]. Idiong, C. I., E. Onyenweaku, E.c., I. A. Domian and B. O. Susan 2007. A Stochastic Frontier Analysis of Technical Efficency in Swamp and Upland Rice Production System in Cross River State, Nigeria. Medwell Agricultural Journal 2(2): 299-305

[13]. KWADP (Kwara Agricultural Development Project), 2008 House Journal and Bulletin, Kwara State

[14]. KWADP (Kwara Agricultural Development Project), 2011. House Journal and Bulletin, Kwara State.

[15]. Muhammed-lawal, A., O.A. Omotesho and A. Falola 2009. Technical Efficiency of Youth participation in Agriculture Programme in Ondo State, Nigeria. J. of Agric. Food and Envt. 5(1): 20-26

[16]. National Bureau of Statistics (NBS) (2013). Poverty Profile for Nigeria. Annual Report, Federal Republic of Nigeria. 2013.

[17]. NPC (National Population Commission) 2006. National Population Commission Sample Survey. 2006,

[18]. Ogundele, A. O. and V. O. Okoruwa, 2006. Technical Efficency Differentials in Rice Production Technolgy in Nigeria. African Economic Consortium, Research Paper No. 154

[19]. Oniah, M.O., O.O. Kuye and I. C. Idiong, 2008. Efficency of Resource Use in Small Scale Swamp Rice Production in Obubra Local Government Area of Cross River State, Nigeria. Middle East Journal of Scientific Research 3(3): 145-148

[20]. Oyewole, S.O. and E. S. Ebukiba 2010. Analysis of Technical Efficiency and its Determinants among Small Scale Rice Farmers in Lafia Local Government Area of Nasarawa State, Nigeria. Agriculture and Biology Journal of North America

[21]. Usman, A. 2011. Analysis of Technical Efficiency and Its Determinants among Small Scale Rice Farmers in Niger State. Unpublished MSc. Dissertation. Department of Agricultural Economics and Rural Sociology, Ahmadu Bello University, Zaria, Nigeria. 